\title{
Climatological Characteristics of Historical and Future High-Wind Events in Alaska
}

\author{
Soumik Basu, John E. Walsh \\ International Arctic Research Center, University of Alaska, Fairbanks, AK, USA \\ Email: sbasu@alaska.edu,jewalsh@alaska.edu
}

How to cite this paper: Basu, S. and Walsh, J.E. (2018) Climatological Characteristics of Historical and Future High-Wind Events in Alaska. Atmospheric and Climate Sciences, 8, 373-394. https://doi.org/10.4236/acs.2018.84025

Received: August 29, 2018

Accepted: October 7, 2018

Published: October 10, 2018

Copyright $\odot 2018$ by authors and Scientific Research Publishing Inc. This work is licensed under the Creative Commons Attribution International License (CC BY 4.0).

http://creativecommons.org/licenses/by/4.0/

(c) (i) Open Access

\begin{abstract}
High winds cause waves, storm surge, erosion and physical damage to infrastructure and ecosystems. However, there have been few evaluations of wind climatologies and future changes, especially change in high-wind events, on a regional basis. This study uses Alaska as a regional case study of climatological wind speed and direction. Eleven first-order stations across different subregions of Alaska provide historical data (1975-2005) for the observational climatology and for the calibration of Coupled Model Inter comparison Project (CMIP5) simulations, which in turn provide projections of changes in winds through 2100. Historically, winds exceeding 25 and 35 knots are most common in the Bering Sea coastal region of Alaska, followed by northern Alaska coastal areas. Autumn and winter are the seasons of most frequent high-wind occurrences in the coastal sites, while there is no distinct seasonal peak at the interior stations where high-wind events are less frequent. An examination of the sea level pressure pattern associated with the highest-wind event at each station reveals the presence of a strong pressure gradient associated with an extratropical cyclone in most cases. Northern coastal regions of Alaska are projected to experience increased frequencies of high-wind events during the cold season, especially late autumn and early winter, when reduced sea ice cover in the late century will leave coastal regions increasingly vulnerable to flooding and erosion.
\end{abstract}

\section{Keywords}

Extreme Winds, Station Data, CMIP5, Wind Climatology, Alaskan Climate

\section{Introduction}

While the most commonly tracked weather and climate variables are temperature and precipitation, wind is often not included in climate assessments despites its high relevance to society. For example, high-wind events directly dam- 
age infrastructure and also serve as drivers of waves, storm surge, coastal flooding, and erosion. Winds also have impacts on the types of vegetation and wildlife in coastal areas as well as inland regions. Finally, winds are important sources of renewable energy. Among the reasons for the relatively few evaluations of climatologies and changes of winds is the lack of comprehensive and homogeneous datasets on near-surface winds. Unlike temperature and precipitation, for which there are various global datasets (at least for land areas, in the case of precipitation), there are no widely used wind datasets, especially in gridded format. This unavailability of wind datasets stems in part from the fact that station-measurements of wind speed have been subject to changes in anemometer height and/or instrument setting, introducing heterogeneities into the station records. Winds are often missing from station compilations such as the Global Historical Climatology Network (GHCN). Daily wind data are available in the Global Surface Summary of the Day (GSOD), which we describe in Section 2 and utilize in this study.

The high latitudes serve as a key example of a region in which assessments of ongoing and future changes in winds are lacking. While individual cyclones in the Arctic and their impacts on sea ice have been studied in recent years (e.g. [1] [2]), comprehensive data-based evaluations of winds, especially high-wind events, are yet to be performed for the Arctic and sub-Arctic. Moreover, evaluations of historical trends in sub-Arctic storminess and wind events have not provided compelling evidence of trends [3]. There are some indications from models of a northward shift of storm tracks over the North Atlantic Ocean [4] but the northern hemisphere observational data do not show a spatially coherent poleward shift in storm tracks [5].

In the broader context, storms are only one factor in the wind climatology of a region. Episodes of calm can be important for insect harassment of wildlife (and humans). At the other end of the spectrum, a high-wind event can occur without a storm in the immediate vicinity as, for example, a strong high pressure system can be associated with a steep pressure gradient. Topography can also play an important role in the location of strong winds. Given the various factors contributing to winds and high-wind events, this paper addresses the climatology and trends of high-latitude winds regardless of the weather systems or processes responsible for the winds. We address both mean wind and high-wind occurrences, although changes in high-wind events (Section 4) are interpretable in terms of changes in storm tracks.

In view of the heterogeneity of observational data on winds, we focus our analysis on the Pacific sector of the Arctic. This sector includes the Alaska region, which has been on the front line of climate change impacts [6], including coastal flooding and erosion as well as the introduction of wind energy into the mix of power sources. Alaska also has a network of stations for which wind measurements over the past few decades are relatively homogeneous (i.e., the 10-meter anemometer height has been standard since the 1980s at key observing 
stations for which hourly wind data are available).

The Arctic region, including Alaska, has warmed in recent decades at a rate that is twice as large as the global mean (e.g., [7] [8]). This polar amplification is due in part to the reduction of sea ice and snow cover, which provides a positive feedback to the warming that drives the loss of snow and ice [9]. Whether or not a large-scale signal of Arctic warming and sea ice loss has yet emerged from the noise of internal variability, climate models project continued Arctic warming and sea ice loss through the 21 st century. Sea ice magnifies the impacts of high-wind events in the Arctic through increased wave activity, coastal flooding, and erosion. The combination of sea ice loss and high wind events increases the risks of vessel (and other infrastructure) icing in waters newly accessible for marine transport and industrial activity [10]. However, the effects of a warming climate on high-latitude storms are difficult to anticipate. On the one hand, the increased surface fluxes of heat and moisture from newly ice-free ocean areas might be expected to fuel more and stronger storms. On the other hand, polar amplification decreases the low-level meridional temperature gradients, reducing the potential for storm activity. Nevertheless, because upper-level temperatures show greater increases in the tropics than in the Polar Regions, upper-level meridional temperature gradients actually increase [11]. Hence, the net effect on baroclinicity cannot be simply related to baroclinic disturbances such as extratropical cyclones [12]. Moreover, the Arctic amplification affects the variability of the jet stream, which is directly linked to the vertically integrated meridional temperature gradient via the thermal wind equation. [13] provided a diagnostic assessment of these connections.

The expectation of increased storm activity in the Arctic is supported by several recent modeling studies. [14] showed enhanced extratropical cyclone activity over the Eurasian Arctic in model projections for the end of the century, while [4] found indications of northward shifts of the major storm tracks during autumn in the late $21^{\text {st }}$-century model projections. However, analyses of observational data have produced mixed results on trends of high-latitude storminess. In earlier studies, [15] found an increase of Arctic cyclone activity, while [16] reported northward shifts of storm tracks over the Northern Hemisphere $(\mathrm{NH})$ over the last several decades of the 20th century. [17] detected a northward shift of cyclone activity, primarily during winter, over Canada during 1953-2002, and this meridional shift was confirmed more generally in a more recent study by the same group [18]. There cent US National Climate Assessment [3] points to a poleward shift of storm tracks over the United States during recent decades. However, [19] found that temporal trends of cyclones in the North Pacific Ocean have generally been weak over the 60-year period ending 2008. The U.S. Global Change Research Program [20] points to an increase of storminess on the northern Alaskan coast and to associated risks of flooding and coastal erosion along with expected sealevelrise. Since any increases of coastal flooding and erosion are also related to retreating sea ice, high-wind events in coastal areas of the 
Arctic can pose increasing risks regardless of whether storm activity is changing.

The present paper is a climatological assessment of high-wind events in and around Alaska, a region in which the possibility of future changes in high-wind events has major implications for planning and adaptation. Our study is motivated by the key question: Are high-wind events likely to increase or decrease in the Alaska region as the climate warms? The paper is organized as follows. Section 2 describes the data and methodology. Section 3 then summarizes the historical information on exceedances of wind speed thresholds at a network of observing stations. These results serve as benchmarks for calibrating global climate models, which are then used in Section 4 to evaluate historical and future changes of mean and extreme winds in a set of global climate models. We conclude in Section 5 with a summary of the key results and their implications, together with recommended next steps to address surface winds in the context of a changing climate.

\section{Datasets and Methodology}

This study examines the historical and future occurrences of extreme wind at 11 stations over Alaska (Figure 1). The set of 11 stations is carefully chosen so that it covers all the geographical regions within Alaska, i.e., the Beaufort Sea coast (Deadhorse and Barrow), Bering Sea coast (Cape Lisburne and Nome), Interior Alaska (Bettles and Fairbanks), south central Alaska (Anchorage), southwest Alaska (Bethel), the Aleutian Islands (St. Paul and Cold Bay), and the southeastern region (Juneau). We examine the observed wind values for the above-mentioned

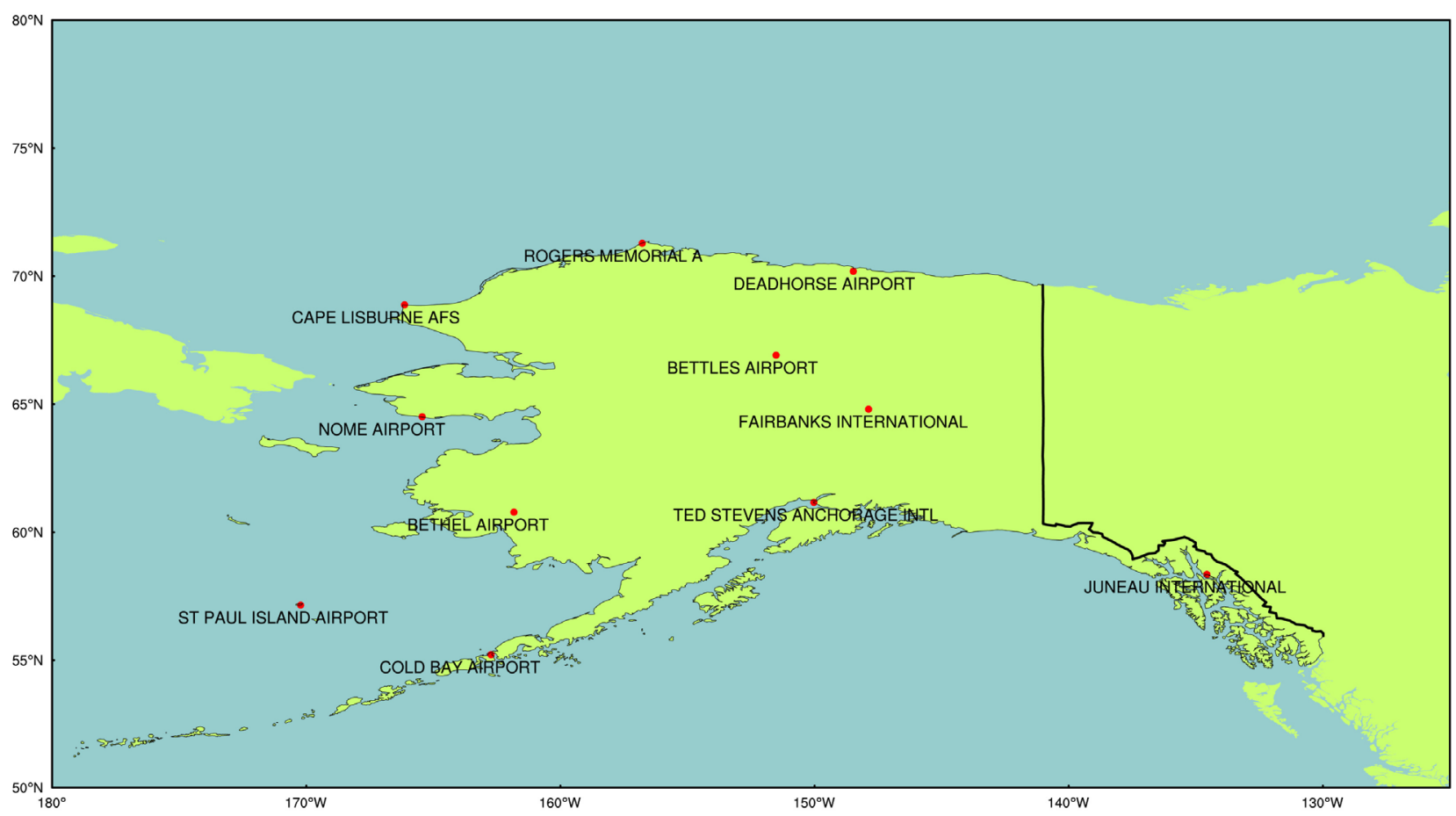

Figure 1. Map showing 11 ISD-Lite stations. 
locations as well as the historical and RCP 8.5 model simulations from the Coupled Model Intercomparison Project (CMIP5). The observed values are obtained from National Oceanic and Atmospheric Administration (NOAA) Integrated Surface Data (ISD)-Lite dataset which consists of the observed hourly values of different atmospheric parameters (air temperature, dew point temperature, sea level pressure, wind direction, wind speed, sky condition, and precipitation) for 35,000 stations worldwide.

The observed wind speed values are used in conjunction with the model data for the historical period (1975-2005) of CMIP5 model simulations. The future (2006 onward) projection of the occurrences of extreme winds uses a future emission scenario (RCP 8.5) from the CMIP5 simulations [21]. Specifically, we extract zonal $(\mathrm{u})$ and meridional $(\mathrm{v})$ component of wind from the historical and RCP 8.5 simulations by six different models: CCSM4, CNRM-CM5, GFDL-CM3, MIROC5, MPI-ESM-LR, and NorESM1-M. These different models were selected from the list of the top performing CMIP5 models for the Alaska region [22] subject to the availability of the highest temporal resolution of model wind data i.e. 6-hourly wind output. Table 1 contains a detailed description of the six models including their full names, home institutions, and spatial resolutions. The ensemble member denoted by r1i1p1 was used for CNRM-CM5, GFDL-CM3, MIROC5, MPI-ESM-LR and NorESM1-M and ensemble member r6ilp1 was used for CCSM4.

Table 1. Details of the CMIP5 models used for this study.

\begin{tabular}{|c|c|c|c|}
\hline Model & Model Full Name & Institution & $\begin{array}{c}\text { Horizontal Resolution } \\
\text { (degree longitude } \times \\
\text { degree latitude) }\end{array}$ \\
\hline $\operatorname{CCSM} 4.0$ & $\begin{array}{c}\text { Community Climate } \\
\text { System Model (CCSM), } \\
\text { version } 4\end{array}$ & $\begin{array}{l}\text { National Center for } \\
\text { Atmospheric Research } \\
\text { (NCAR), United States }\end{array}$ & $1.3 \times 0.9$ \\
\hline CNRM-CM5 & $\begin{array}{l}\text { Centre National de } \\
\text { Recherches } \\
\text { Meteorologiques } \\
\text { (CNRM) Coupled } \\
\text { Global Climate Model, } \\
\text { version } 5\end{array}$ & $\begin{array}{l}\text { CNRM-Centre Europeen } \\
\text { de Recherche et de } \\
\text { Formation Avancee en } \\
\text { Calcul Scientifique } \\
\text { (CERFACS), France }\end{array}$ & $1.4 \times 1.4$ \\
\hline MIROC5 & $\begin{array}{l}\text { Model for Interdisciplinary } \\
\text { Research on Climate } \\
\text { (MIROC), version } 5\end{array}$ & $\begin{array}{l}\text { Atmosphere and Ocean } \\
\text { Research Institute, } \\
\text { University of Tokyo, Japan }\end{array}$ & $1.4 \times 1.4$ \\
\hline GFDL-CM3 & $\begin{array}{l}\text { Geophysical Fluid } \\
\text { Dynamics Laboratory } \\
\text { (GFDL) climate } \\
\text { Model version } 3\end{array}$ & $\begin{array}{c}\text { Geophysical Fluid } \\
\text { Dynamics Laboratory, } \\
\text { United States }\end{array}$ & $2.5 \times 2.0$ \\
\hline NorESM1-M & $\begin{array}{c}\text { Norwegian Earth System } \\
\text { Model }\end{array}$ & $\begin{array}{l}\text { Norwegian Climate Centre } \\
\text { (NCC), Norway }\end{array}$ & $2.5 \times 1.9$ \\
\hline MPI-ESM-LR & $\begin{array}{l}\text { Max Planck Institute } \\
\text { (MPI) Earth System } \\
\text { Model, low resolution }\end{array}$ & $\begin{array}{c}\text { Max Planck Institute, } \\
\text { Germany }\end{array}$ & $1.9 \times 1.9$ \\
\hline
\end{tabular}


The 6-hourly CMIP5 model output has 3 pressure levels i.e. $850 \mathrm{hPa}, 500 \mathrm{hPa}$, and $250 \mathrm{hPa}$. Thus, for a comparison with the surface wind speed values obtained from NOAA ISD-Lite dataset, it was necessary to extrapolate to $1000 \mathrm{hPa}$ the wind speed at the lowest model levels of all the CMIP5 models.

For analyzing the occurrences of extreme wind over the 11 observational stations across Alaska, a threshold wind speed $(\mathrm{m} / \mathrm{s})$ was calculated based on the standard deviation of the ISD-lite station data for each station. A6-hourly wind speed of 2 standard deviations above the 6-hourly wind speed value at each station was the threshold for an extreme wind at that station. The location of each of the 11 observing stations was used to locate the nearest grid point to that station in each model. The number of 6-hourly time-steps exceeding the threshold wind speed was evaluated from the ISD-lite station data, and from the historical and RCP 8.5 output of the six CMIP5 models. The numbers of occurrences of extreme wind in the models are for the nearest grid point to the location of each ISD-Lite station.

The climate models are known to have biases. In an effort to minimize the effect of the bias a correction factor [23] was then calculated for each model's winds for each station and each month. The correction factor is calculated as follows:

Correction factor $=\frac{\text { No. of time steps exceeding the threshold wind speed value in the station data }}{\text { No. of time steps exceeding the threshold wind speed value in CMIP5historical data }}$

This bias adjustment effectively normalizes the models' winds so that the frequencies of their high-wind events are consistent with the historical observational data. By applying the same adjustment to the models' future output, we are making the assumption that the models' biases do not change systematically in the future. Similar assumptions are made in bias-corrections of model projections of other variables, e.g., temperature and precipitation, when the Delta-method is applied in downscaling applications [24] [25] [26]. While there is no proof that this assumption is valid, we are not aware of any evidence to the contrary.

\section{Observational Data Synthesis}

Figure 2 shows the seasonal cycle of the climatological monthly mean wind speed at each station for each month. The mean wind speeds are lowest at the interior stations (Bettles, Fairbanks), nearly as low at the topographically sheltered locations (Anchorage, Juneau), and highest at the stations located in the Aleutian storm track (St. Paul, Cold Bay). The wind speeds averaged over the 11 stations are about $5 \mathrm{~m} \cdot \mathrm{sec}^{-1}$ throughout the year. The monthly wind speed exhibits a distinct seasonal distribution at some of the stations. The interior stations have the highest observed wind speeds in April-May, while the coastal stations located in the Aleutian storm track have their highest mean wind speeds in the winter months. The northern coastal stations of Barrow and Cape Lisburne show the strongest winds in autumn, although the autumn peak is weak at Barrow. 

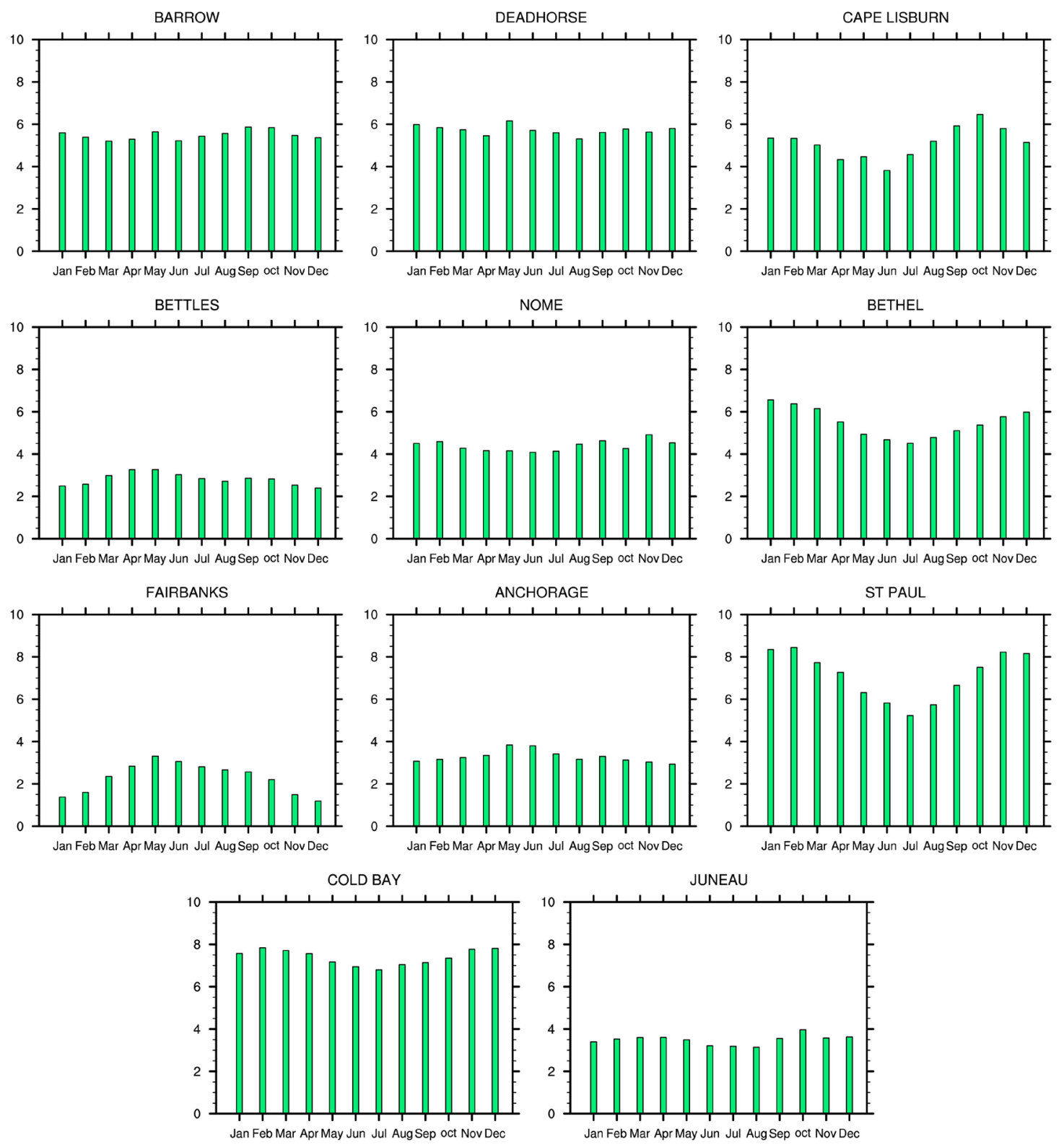

Figure 2. Long term monthly mean (climatology) wind speed $(\mathrm{m} / \mathrm{s})$ for each of the stations shown in Figure 1 .

Figure 3 and Figure 4 summarize the numbers of high-wind occurrences during the 1975-2005 at the 11 stations shown in Figure 1. Because the CMIP5 models are driven by the RCP forcing after 2005, we performed the evaluation over the 1975-2005 period for consistency with the historical climate model output in the following section. Figure 3 shows the total number of hours per year in each calendar month with reported winds in excess of 25 knots (12.9 $\left.\mathrm{m} \cdot \mathrm{sec}^{-1}\right)$, which is approximately 2.5 times the 11 -station mean wind speed. (Winds at observing stations in the U.S. are reported in knots). There is a strong seasonal cycle in the occurrence of winds exceeding 25 knots at all but the two interior stations (Fairbanks and Bettles). The October-through-February cold season is the time of year with greatest numbers of highwind occurrences at the 

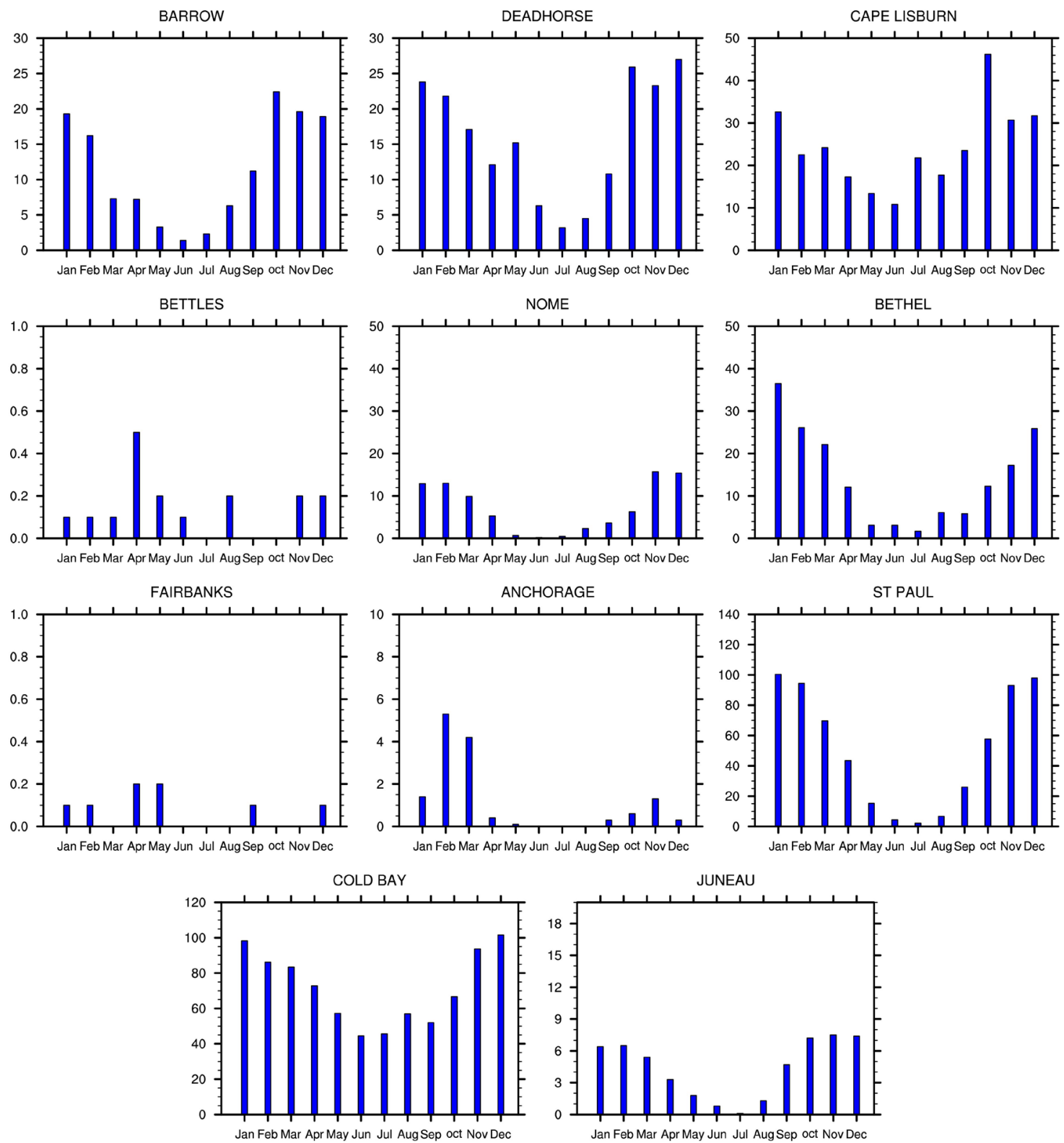

Figure 3. Number of hourly time-steps with wind speeds exceeding 25 knots. Numbers on y-axis are hours per calendar month averaged over 1975-2005.

coastal sites, consistent with the seasonality of cyclones affecting Alaska [15] [19]. Figure 3 also shows that there is a wide geographical range in the frequency of strong winds. In the Interior of Alaska, the average frequency of 25-knot winds is well below one hour per year in each calendar month. At both Fairbanks and Bettles, most years have no such events in each calendar month. For Fairbanks, hourly winds of 25 knots are once-in-five-year events in even the windiest calendar months, April and May. At Bettles, such winds are more frequent than once-in-five-years only in April. At the coastal sites, however, the frequencies of 25 knot winds are much greater, with monthly averages exceeding 20 hours during the cold season at Barrow, Cape Lisburne, and Bethel. By contrast, 

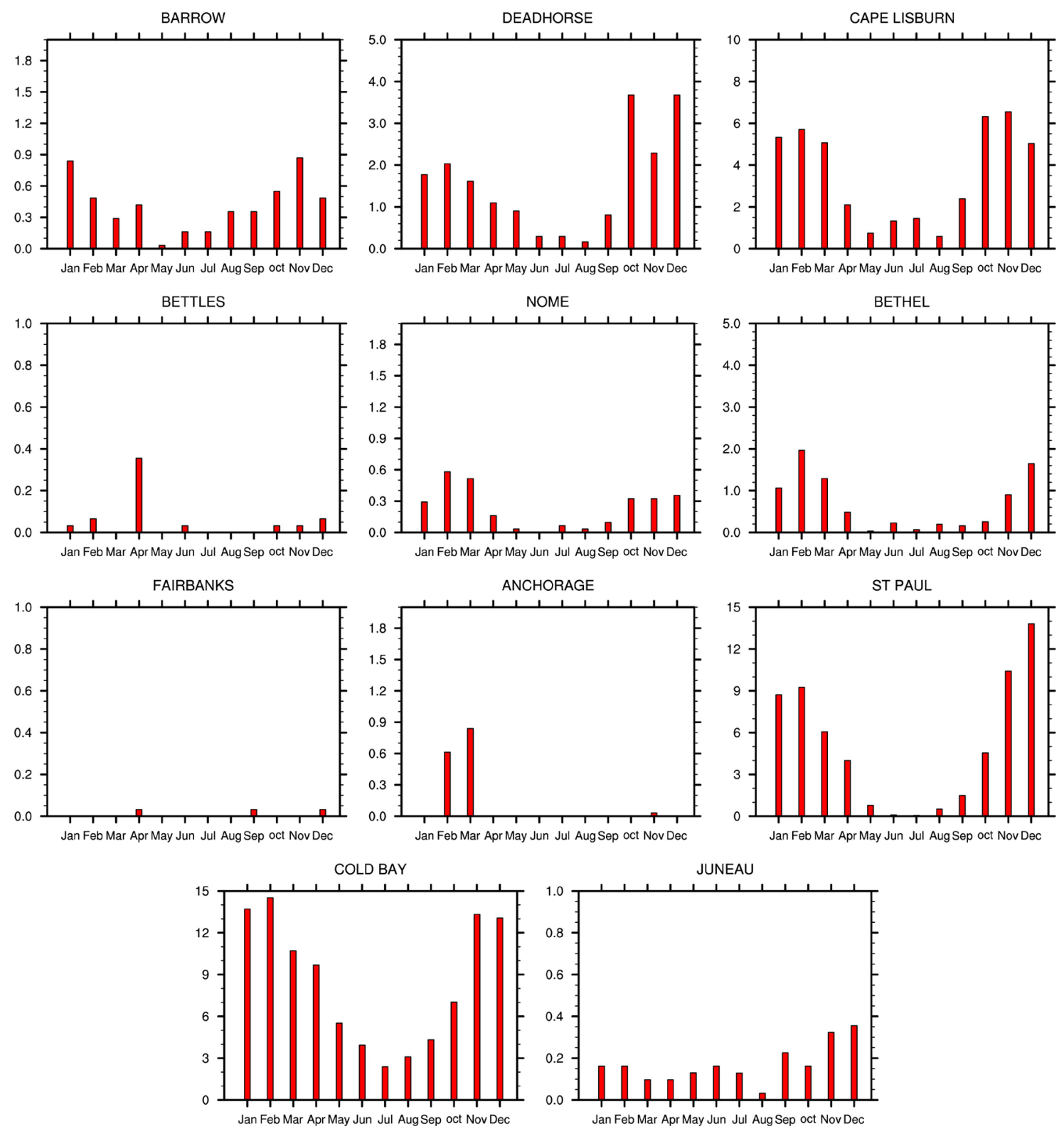

Figure 4. As in Figure 3, but for wind speeds exceeding 35 knots.

the monthly averages for November-January reach approximately 100 hours at St. Paul (in the Bering Sea) and Cold Bay(in the Aleutians), which are located close to the main Aleutian storm track during these months. Maximum monthly frequencies in the intermediate range (5 to 15 hours) are found at some of Alaska's larger population centers: Anchorage, Juneau, and Nome.

Wind speeds exceeding $35 \mathrm{knots}\left(18 \mathrm{~m} \cdot \mathrm{sec}^{-1}\right)$ are in the category of gale-force as defined by the US National Weather Service (34 - 47 knots) and the Beaufort wind scale (34 - 40 knots). The occurrence or anticipation of winds of this magnitude generally leads to the issuance of warnings by weather services. The plots in Figure 4 imply that winds exceeding 35 knots in Interior Alaska are rare (occurring less often than once in 10 years in most calendar months. However, their 
frequencies of occurrence exceed one hour per month at a geographically wide range of Alaskan coastal sites: Deadhorse on the Beaufort Sea coast (2 to 4 hours per month during October-March); Cape Lisburne on the Chukchi Sea coast (4 to 6 hours per month during October-March); Bethel, near the southwestern Alaska coast ( 1 to 2 hours per month during November-March); St. Paul in the Bering Sea ( 9 to 13 hours per month during November-February); and Cold Bay in the Aleutians ( 10 to 15 hours per month during November-April). The maximum monthly average frequencies are in the range of 0.5 to 1.0 hours per year at Nome, Anchorage and Juneau with seasonalities consistent with the 25-knot exceedances in Figure 3. Because winds of this magnitude often lead to large waves, coastal erosion, flooding, and direct wind damage, we address the anticipated changes in these frequencies based on global climate models in Section 4.

In order to illustrate the types of events that are represented in the seasonal statistics of Figure 3 and Figure 4, we present maps in Figure 5 of the sea level pressure during the highest hourly wind events during 1975-2005 at each of the 11 ISD-Lite stations. While the positioning of the pressure systems varies among the stations, there are two commonalities among the events at the 11 stations: 1)

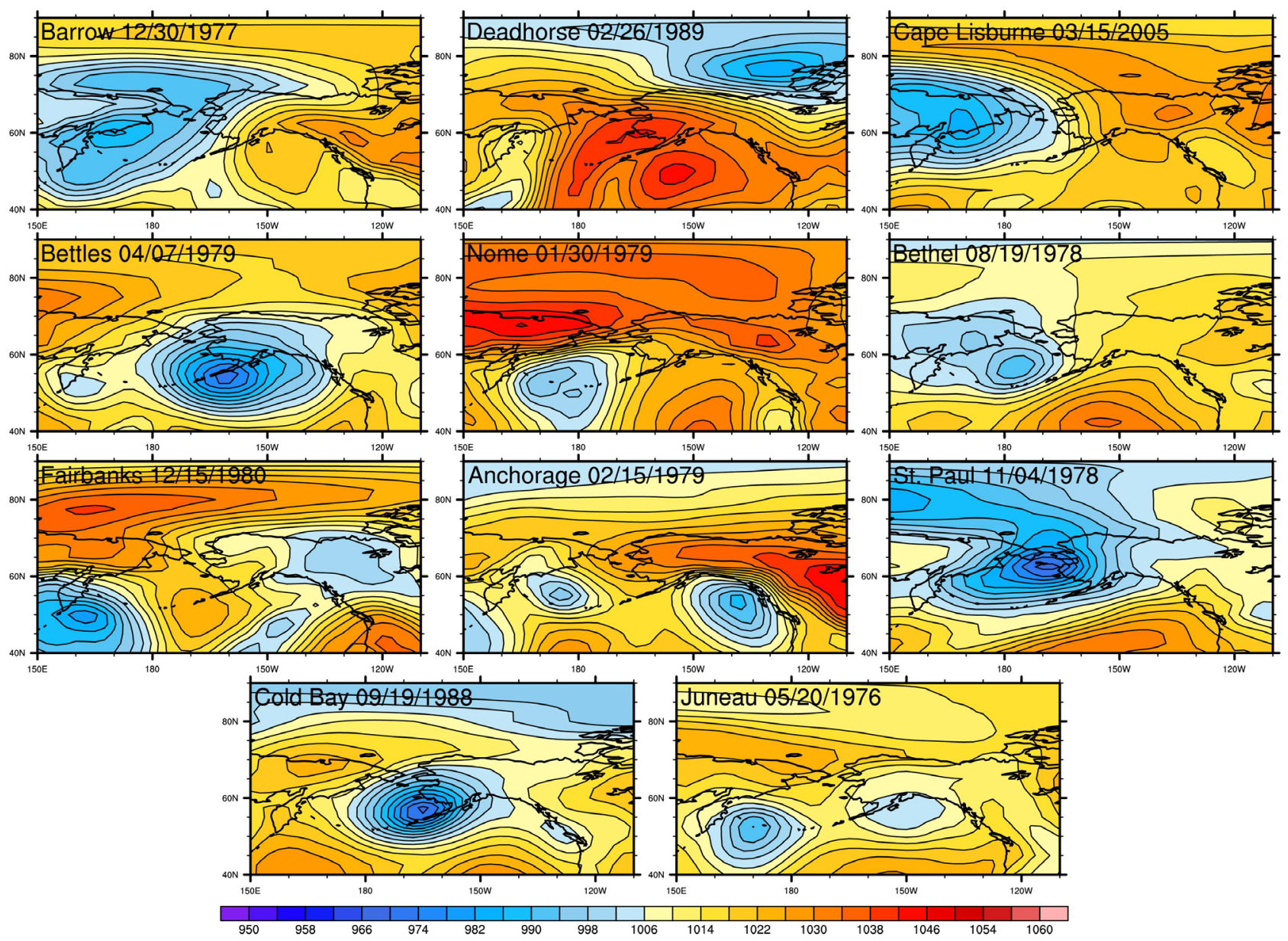

Figure 5. Maps of sea level pressure (hPa) in the Alaska region at the times of hourly observations with strongest wind speeds of the 1975-2005 period at each of the 11 ISD-Lite stations. Station identifiers are in upper left corner of each panel. 
a strong pressure gradient and 2) a low pressure system (cyclone) in the vicinity of the station. The cyclone is generally a strong one, with central pressures below 980 $\mathrm{hPa}$ in various cases (Cold Bay, St. Paul, Bettles, Cape Lisburne). In most cases, there is also a strong high pressure system nearby, adding to the strength of the pressure gradient. Deadhorse, Nome, Anchorage, and St. Paul cases are good examples of the juxtaposition of high and low pressure centers resulting in strong gradients over the stations. At the two stations with significant topography nearby (Anchorage, Juneau), the pressure patterns are conducive to downslope flow, which likely adds a mesoscale perturbation that increases the wind speed locally.

The impacts of high-wind events are generally a function of wind direction. Winds with an onshore component are more conducive to elevated sea level and greater impacts on coastlines thana similarly strong winds with an offshore component. Figure 6 shows the distributions of wind directions during the
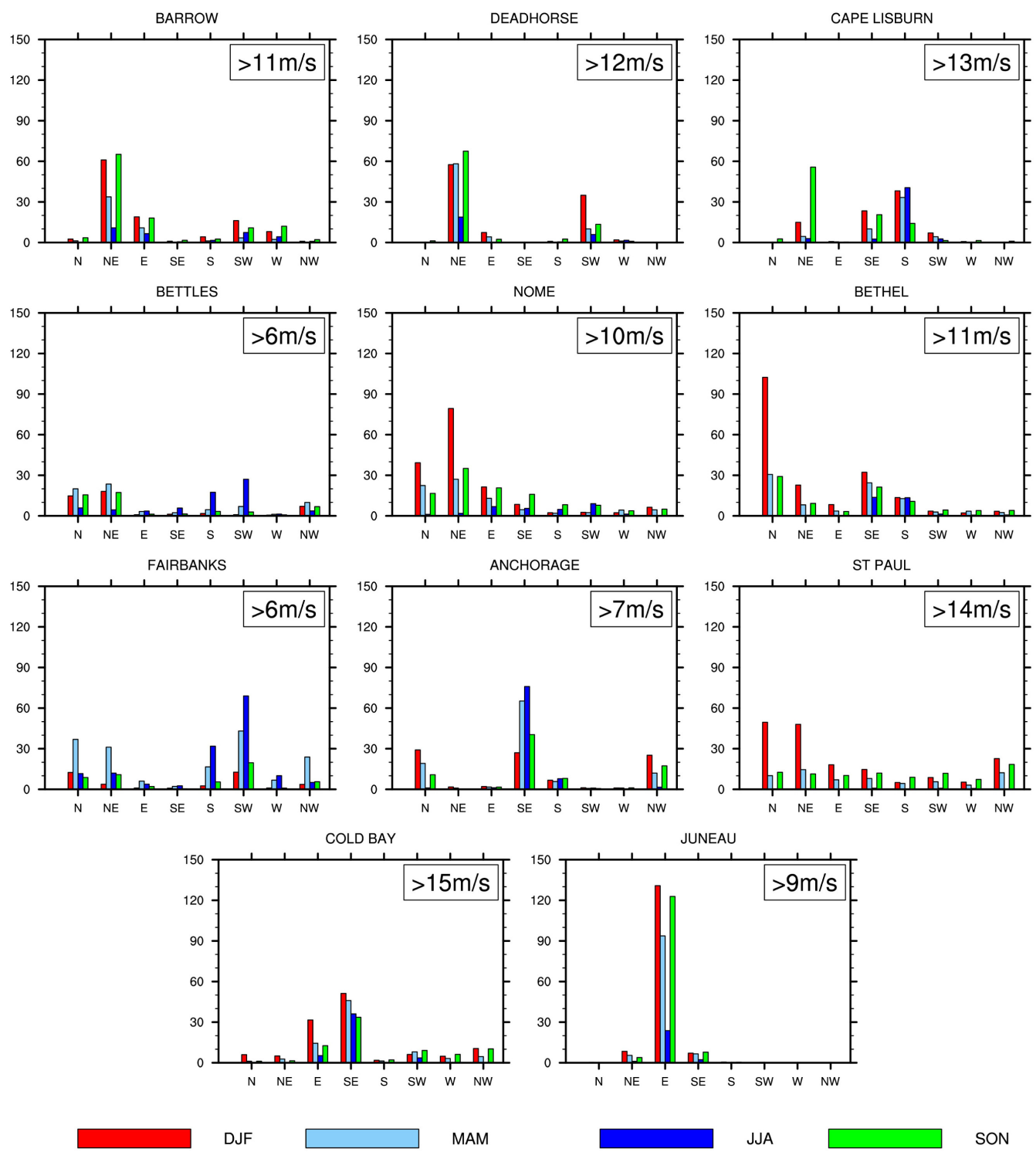

Figure 6. Distribution of wind direction during high-wind events at ISD-Lite stations. 
6-hourly high wind events exceeding the station-specific two-standard deviation thresholds described in Section 2. The figure distinguishes the wind events by season. It is apparent that there are preferred directions for the high-wind events at most stations. Along the northern coast (Barrow, Deadhorse) northeasterly wind events dominate, consistent with the presence of a Beaufort anticyclone to the north [27] [28]. A secondary peak of southwesterly wind events at the northern coastal stations is associated with cyclones tracking offshore of the coastal sites. Bering Sea cyclones shape the distributions at coastal stations such as Nome, Bethel, St. Paul and Cold Bay, where the high-wind events are most common during winter and the most common directions are northerly or northeasterly. These directions imply that the cyclone centers are located to the east or south of the stations. Interior sites (Fairbanks, Bettles) show peaks corresponding to summer southwesterly events and autumn northeasterly events, while the distributions at coastal sites near mountains show peaks corresponding to downslope winds: easterly at Juneau, southeasterly at Anchorage), consistent with the examples in Figure 5. Overall, the distributions in Figure 6 are consistent with the seasonal distributions of the hourly events in Figure 3 and Figure 4 , with summer minima at the coastal sites and more seasonally varied distributions at the interior sites.

\section{Projections of Future Changes}

In order to anticipate changes in the winds over the Alaska region in the future, we utilize the CMIP5 models simulations driven by the RCP 8.5 scenario, which is the RCP scenario that is presently tracking actual emissions most closely. As noted in Section 2, output was utilized from the top-performing global climate models for the Arctic, and a bias-adjustment based on the models' historical simulations was applied to the future output. We present here the differences between the output for 2070-2100 and the 1975-2005 historical period from three models that best capture the climatological seasonal cycle of sea level pressure over Alaska [26]: (a) CCSM4, (b) CNRM CM5, and (c) MIROC5. Figure 7 shows the differences (future minus historical) in the annual mean wind speeds simulated by the three models. While the details of the spatial pattern differ, all three models show general increases over most of Alaska. CCSM4 and MIROC5 project the largest increases over northern Alaska and the offshore Beaufort and Chukchi Seas. CMRM CM5 shows bands of increased wind speeds over the northern and southeastern Alaska coastal regions, with slight decreases over the Bering Sea. Given that the magnitudes of the annual mean wind speeds $\sim 5$ $\mathrm{m} \cdot \mathrm{sec}^{-1}$, the increases of $\sim 0.5 \mathrm{~m} \cdot \mathrm{sec}^{-1}$ represent changes of approximately $10 \%$ in the areas of the largest change.

The seasonality of the projected changes in wind speed is shown in Figure 8 as averages across the three models. The band of strongest increases, approaching $1.0 \mathrm{~m} \cdot \mathrm{sec}^{-1}$ in all seasons except spring, shows a seasonal migration from the $60-70^{\circ} \mathrm{N}$ latitudinal band in winter to approximately $80^{\circ} \mathrm{N}$ in summer. The 

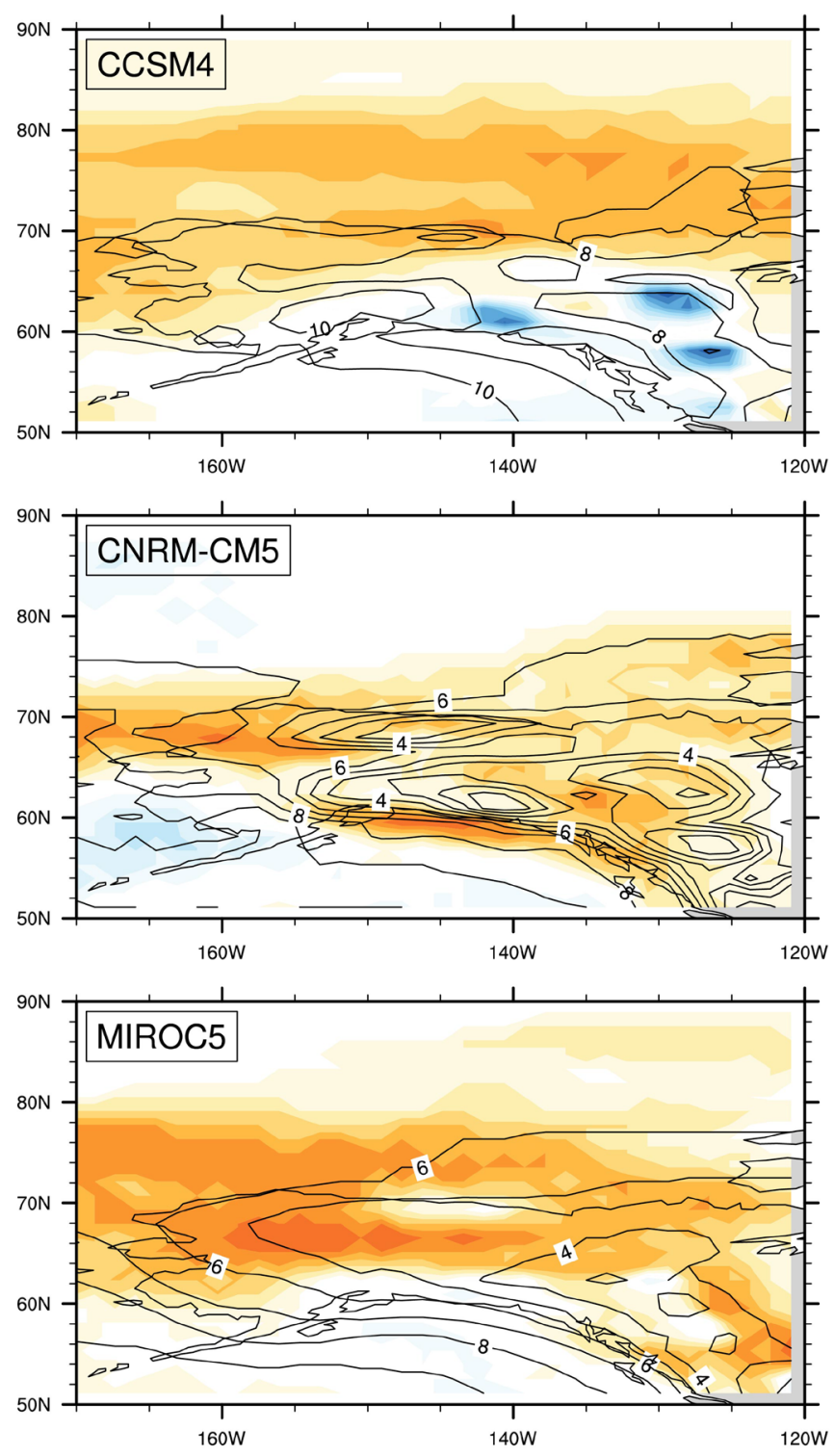

Figure 7. (a) CCSM4, (b) CNRM CM5, (c) MIROC5: Wind Speed (m/s) climatology (non-shaded contours); Wind speed (m/s) difference, RCP 8.5 (2070-2100) minus historical (1975-2005) annual average.

summer and autumn maxima correspond to the approximate latitudes of the sea ice margin, which is generally a zone of enhanced baroclinicity. The increase in summer and autumn is also consistent with the recent finding of [29] that Arctic frontal zone and associated cyclone activity are expected to increase in the future as the sea ice cover diminishes.

A primary objective of the present study is an evaluation of the expected changes in high-wind events over the Alaskan region. For this evaluation, we utilize the three models summarized above, and three additional models that also rank among the top-performing models in historical simulations of Alaskan climate [26]: GFDL-CM3, MPI-ESM-LR, and NorESM1-M. The results are presented for the six individual models in Figure 9, which shows the number of 

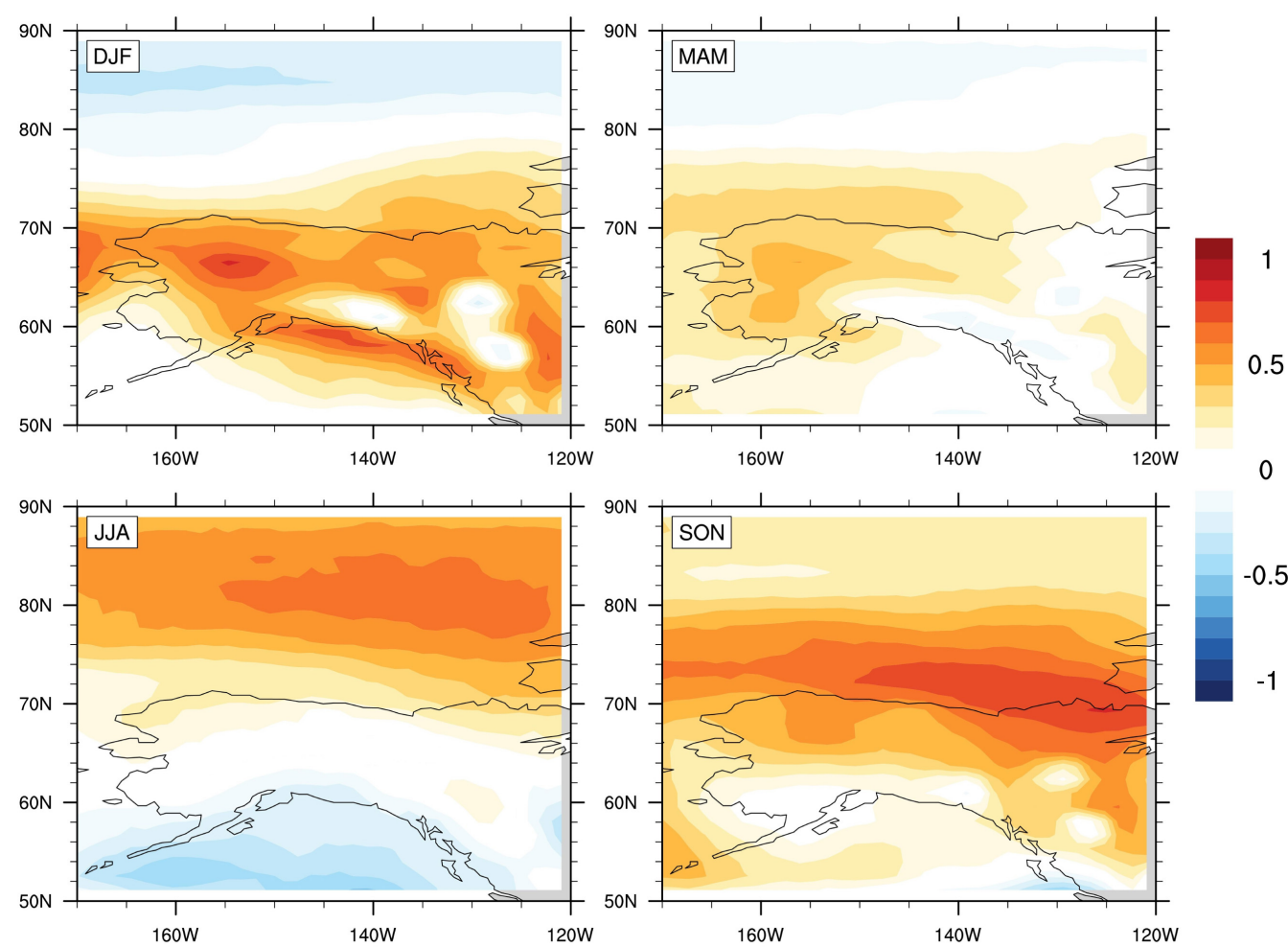

Figure 8. All-model average of seasonal mean wind speed differences (m sec-1), RCP 8.5, 2070-2100 minus Historical (1975-2005). Panels are for winter, Dec-Feb (upper left); spring, Mar-May (upper right); summer, Jun-Aug (lower left); autumn, Sep-Nov (lower right).

threshold exceedances in the model grid cells containing the eleven locations for which station-specific thresholds of 6-hourly wind speeds were obtained (Section 2). For each of the eleven grid cells, the threshold exceedances are shown for each calendar month of the historical and future time slices. The general seasonal cycle (maxima in the cold season, minima in the warm season) found in the data for the coastal stations in Figure 3 and Figure 4 is also apparent in the model results for the coastal grid cells. This seasonality is apparent in the historical as well as the future results. The absence of a seasonal cycle is apparent at the interior locations (Bettles, Fairbanks, and even Anchorage).

The actual changes show some variation among the models and among the stations, but some general patterns are apparent in the results. For the northern coastal stations (Barrow, Deadhorse, Cape Lisburne), increases are generally projected throughout the year, with the largest increases during October through January. The increases are most widespread across the calendar months and the three stations in the CCSM4, CNRM CM5, and NORESM1-M models. The same general seasonal pattern of increase is apparent, although somewhat weaker, for the western Alaska coastal sites, Nome and Bethel. The southwestern sites, St. Paul and Cold Bay, show a mixed pattern of changes, with a general tendency across the models for increases in the October-December and decreases in January-March. At the other sites (Bettles, Fairbanks, Anchorage), there is no consistent sign of the changes. 

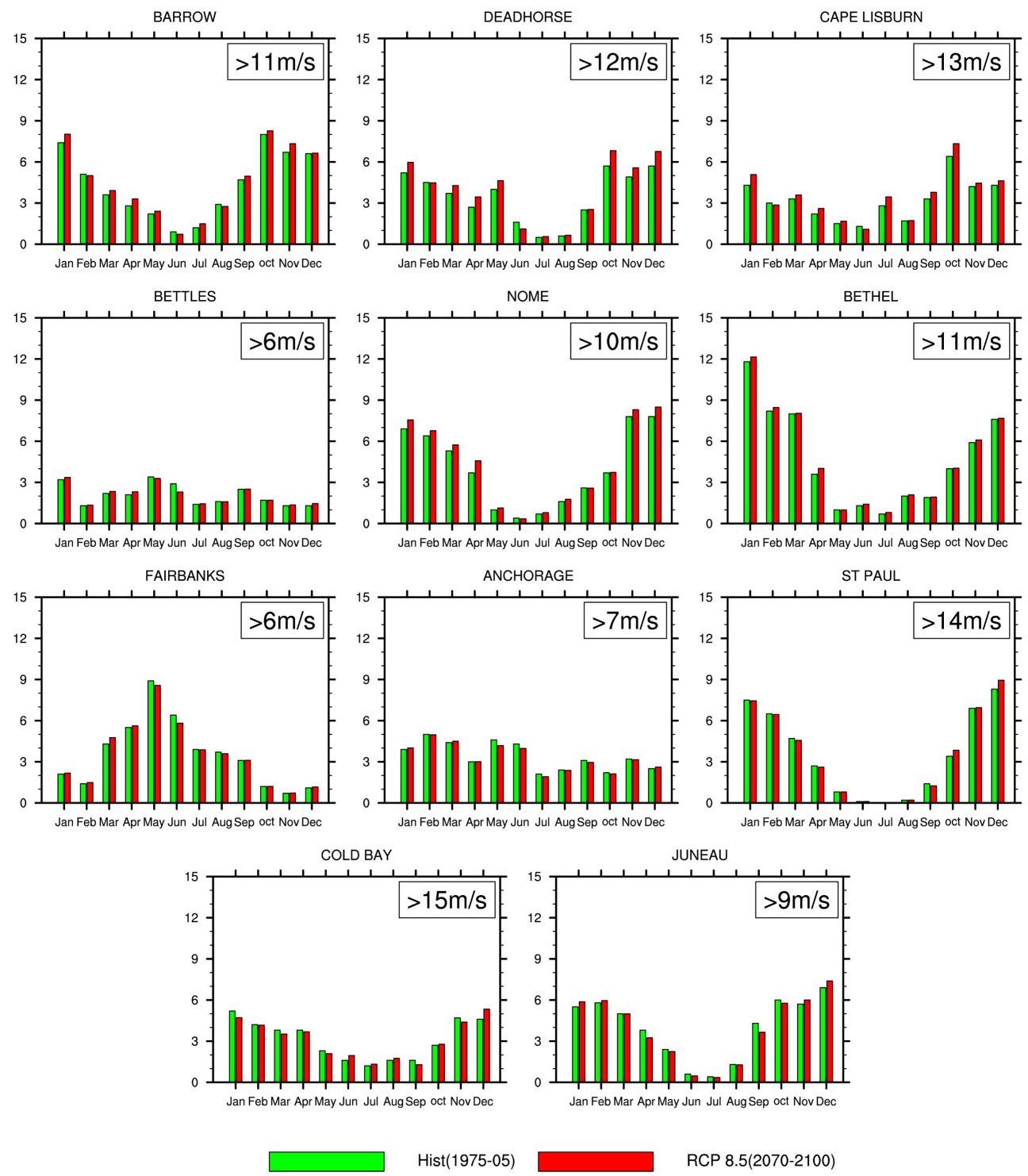

(a)
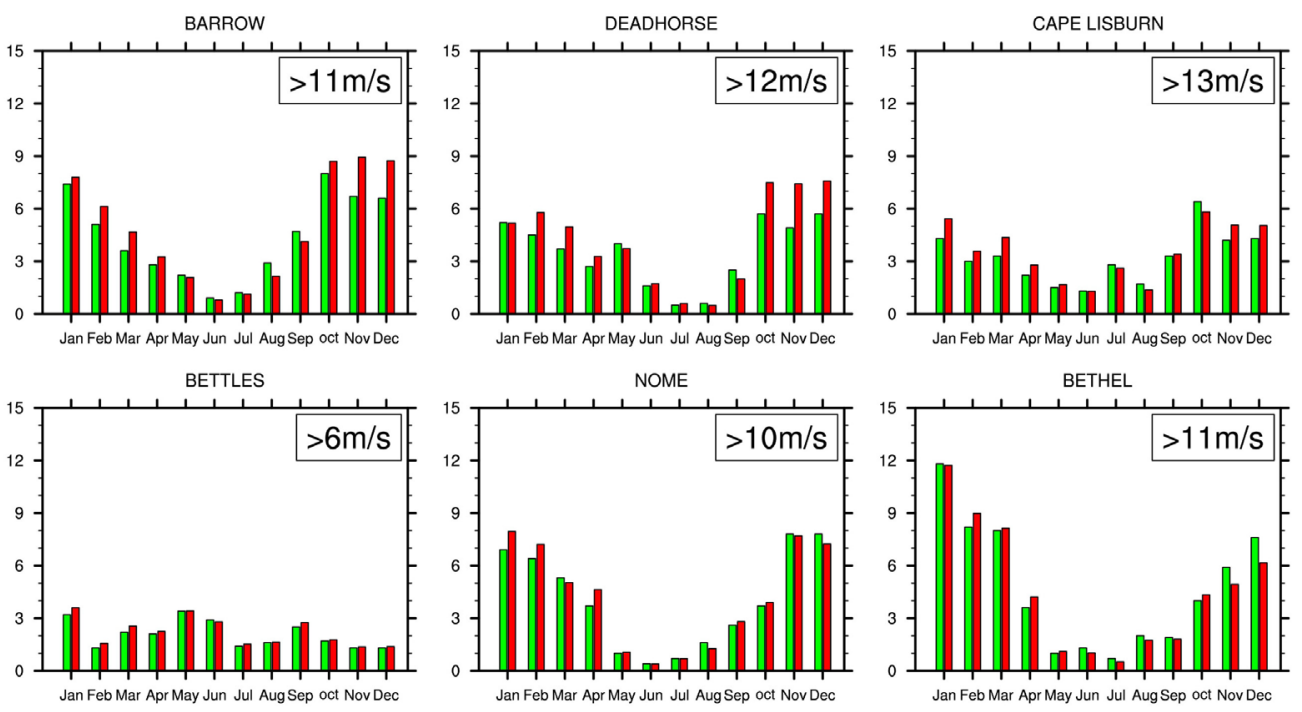


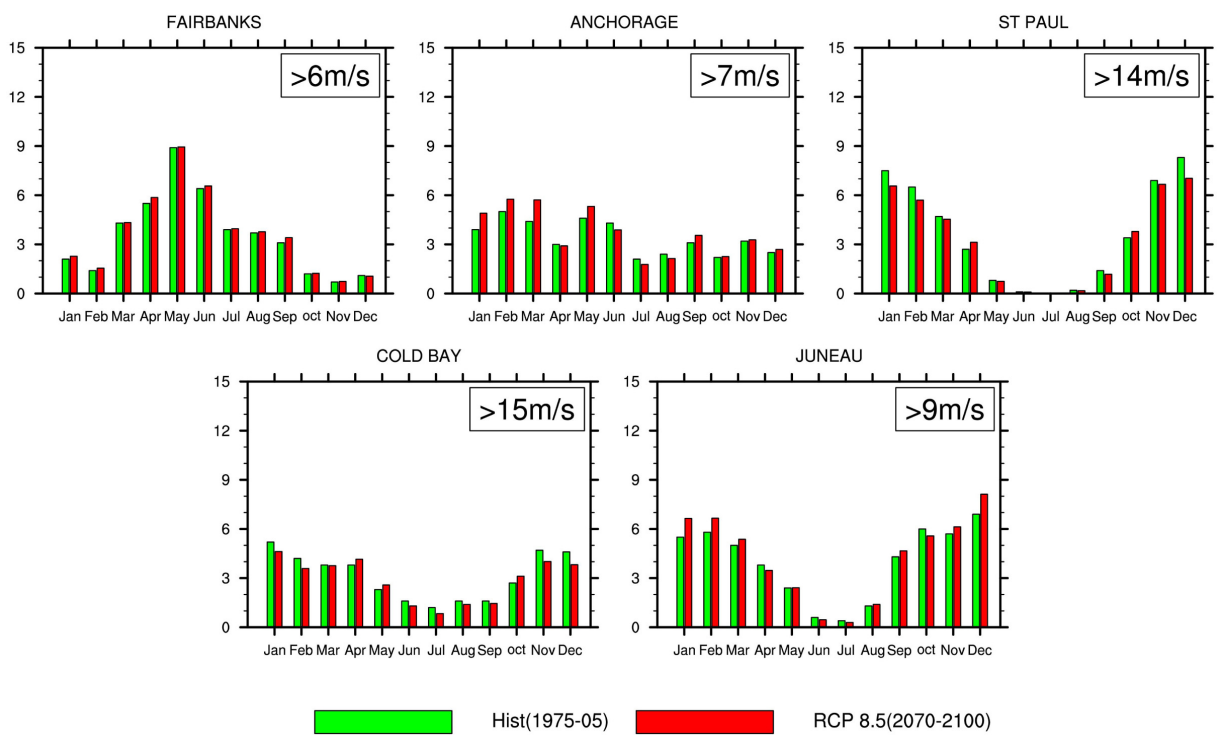

(b)
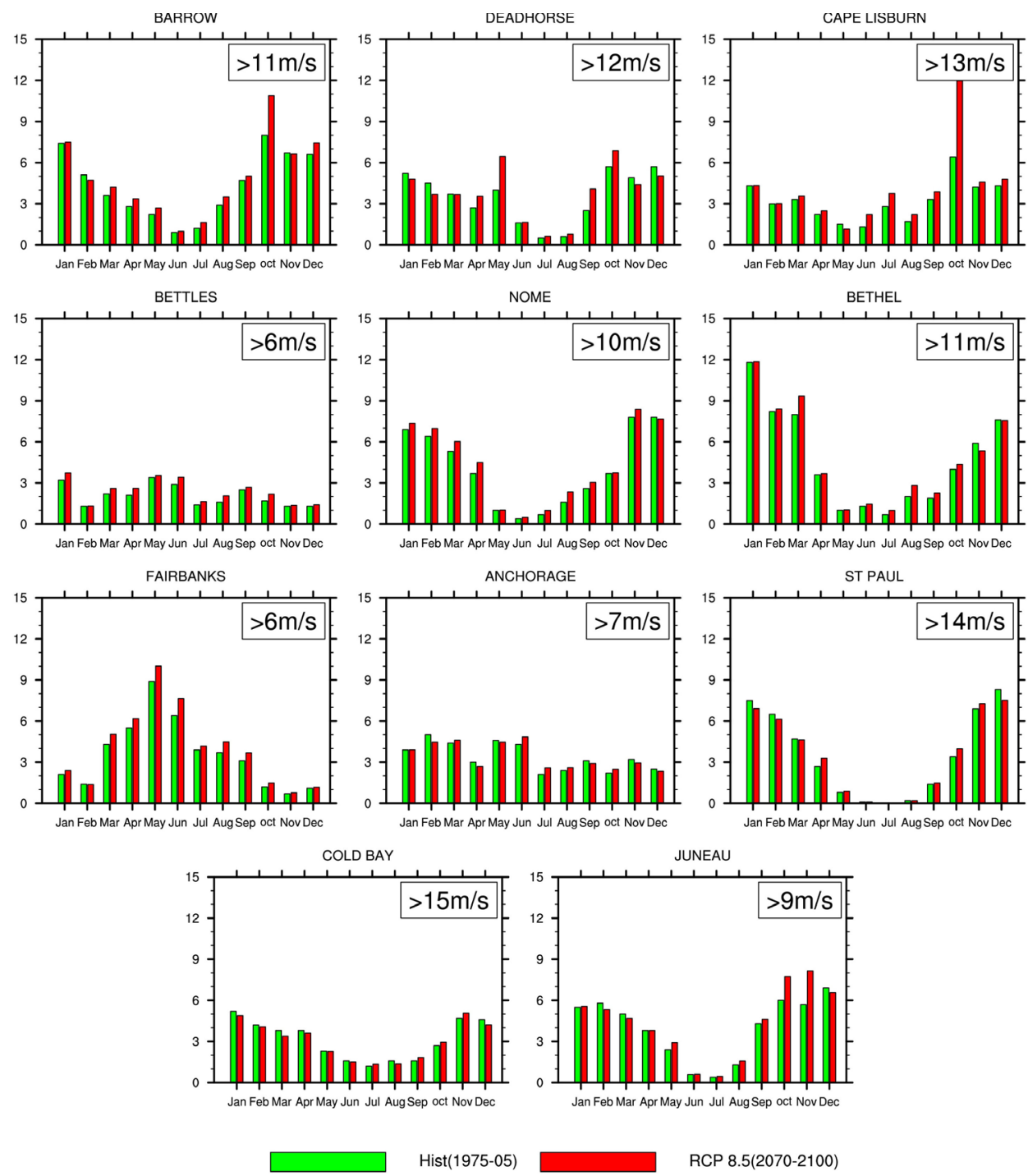

(c) 

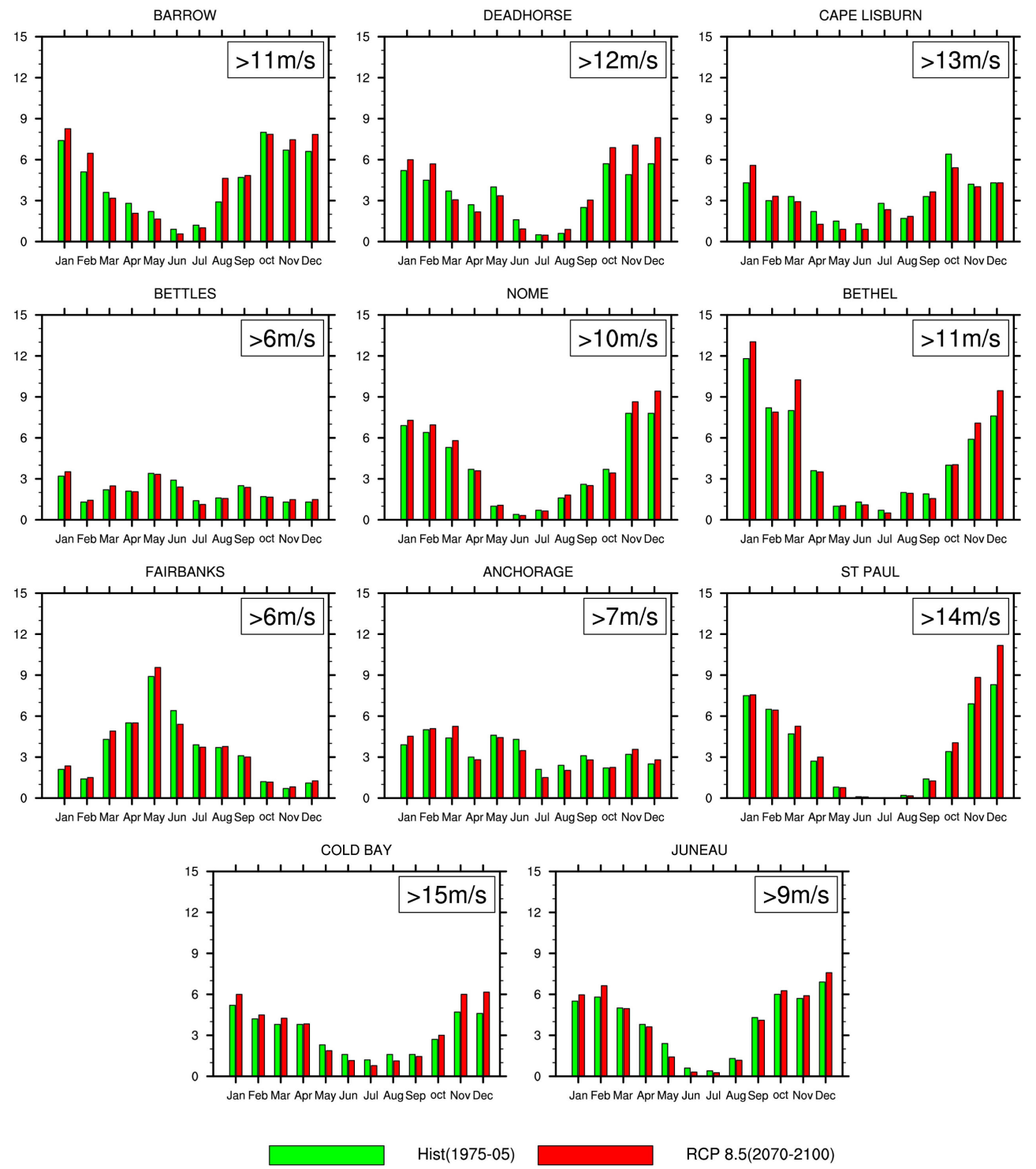

(d)
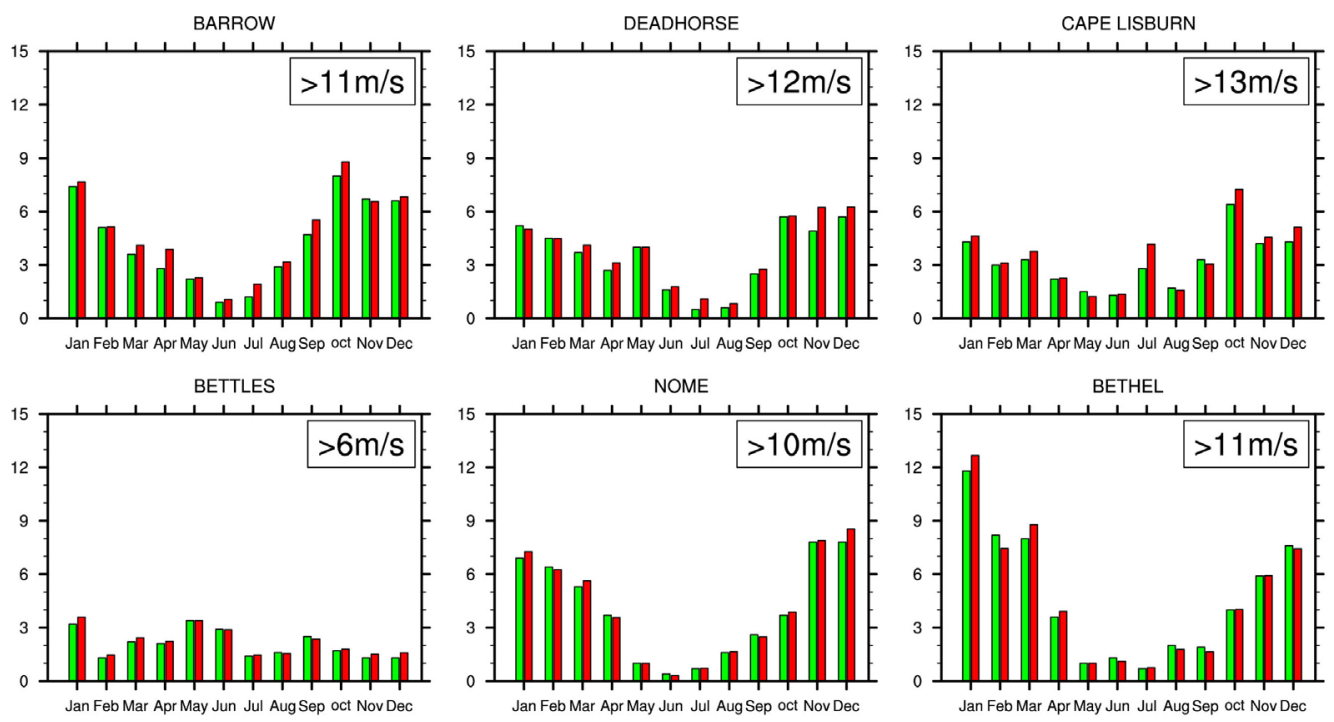


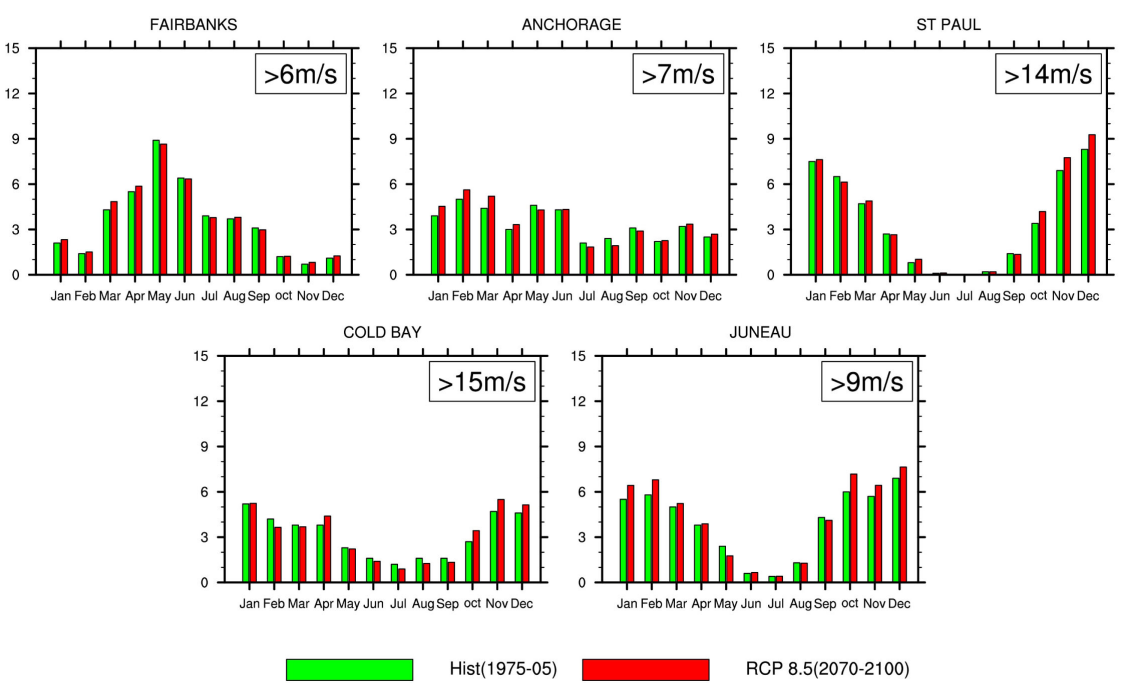

(e)
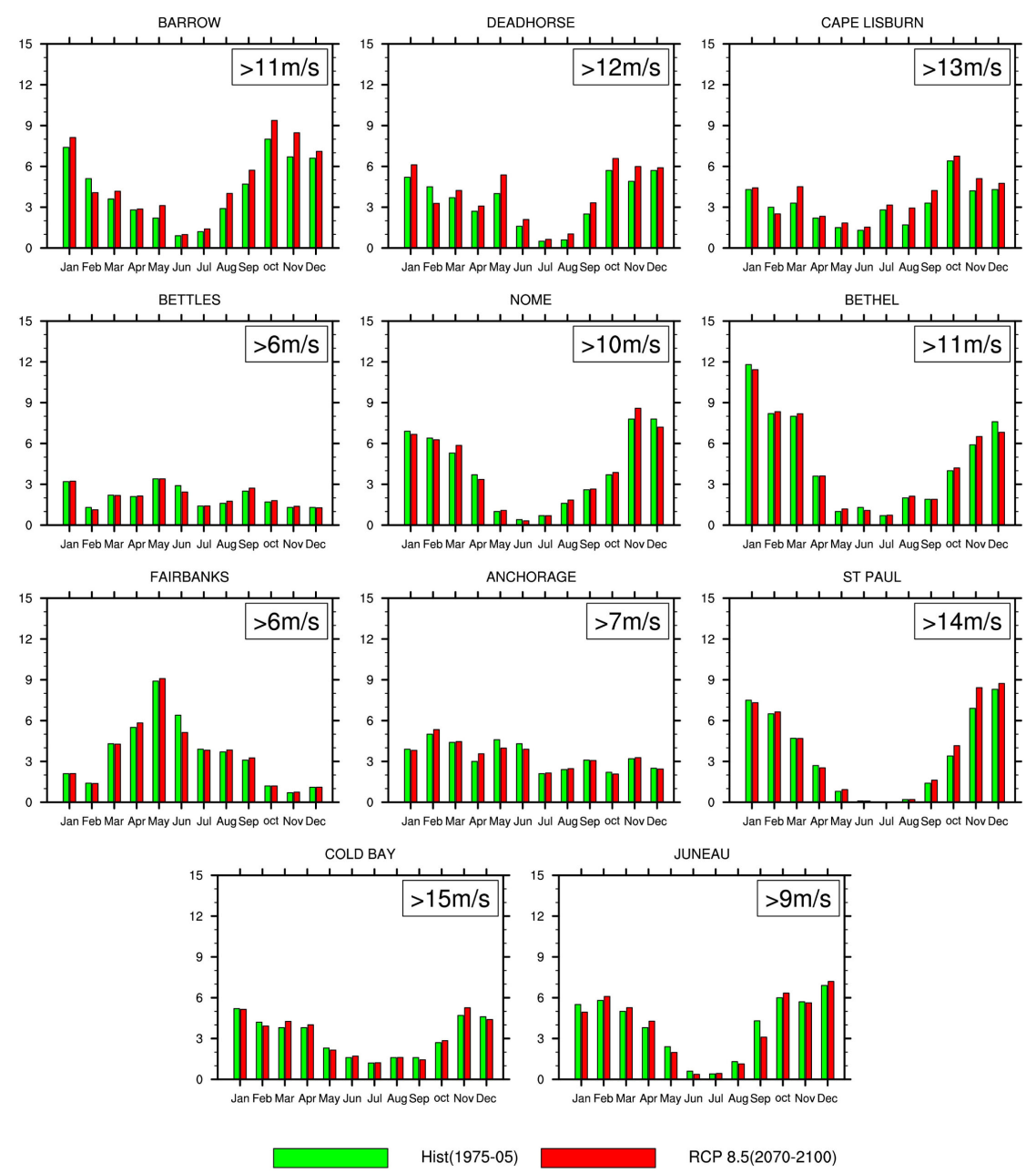

(f)

Figure 9. (a) Number of 6-hourly winds exceeding thresholds (see text) at 11 locations in the CCSM4 model simulations: Historical (green bars), RCP 8.5 2070-2100 (red bars); (b)-(f): As in Figure 9(a), but for (b) CNRM-CM4, (c) MIROC5, (d) GFDL-ESM2M, (e) MPI-ESL-LR, (f) NORESM-M. 


\section{Conclusions}

We have synthesized information on high-wind events from station observations and model simulations in order to provide a climatological baseline for studies of changing vulnerabilities of a high-latitude region, Alaska, for which there is a database of hourly winds extending back to the 1970s. Winds exceeding 25 and 35 knots are most common in the Bering Sea coastal region of Alaska, followed by coastal areas of northern Alaska. Autumn and winter are the seasons of most frequent high-wind occurrences in the coastal areas, while there is no distinct seasonal peak at the interior stations where high-wind events are much less frequent. The wind directions during the high-wind events are consistent with cyclones tracking into the Bering Sea and inland Alaska, often with high pressure to the north or east. Topography appears to play a key role in determining the directions of high winds at stations near mountains (Juneau, Anchorage).

The station data allow for bias-corrections of global climate models, which enable an extension of the analysis to gridded fields for the entire Alaskan region as well as to a future period. The main outcome of this assessment is that the northern coastal regions of Alaska are projected to experience increased frequencies of high-wind events during the cold season, especially late autumn and early winter. Such increases would be especially consequential for the coastal locations from Nome northward because those locations have historically been protected by sea ice from November onward (and from October onward at Deadhorse and Barrow). The longer open water season increases the risk of coastal flooding and erosion, and this risk will be exacerbated by an increase in high-wind events.

Priorities for future work include the direct use of near-surface winds rather than vertically extrapolated winds from the global climate models. We anticipate that the upcoming CMIP6 simulations will make 6-hourly or hourly surface winds available so that a direct comparison can be made with the hourly station data. In addition, a more comprehensive synoptic-scale analysis of the high-wind events should be made to determine the consistency of the synoptic forcing patterns across different events at a particular location. The relative importance of cyclones and anticyclones, especially their juxtapositions, in producing high winds over the various subregions of Alaska, also deserves further investigation. The anticipated continuation of the loss of sea ice makes Alaska a natural focus for this type of analysis.

\section{Acknowledgements}

This publication resulted in part from research sponsored by the Cooperative Institute for Alaska Research with funds from the National Oceanic and Atmospheric Administration under Cooperative Agreements NA13OAR4320056 with the University of Alaska. JW was supported by the National Science Foundation's Arctic Program through Grant ARC-1602720. 


\section{Conflicts of Interest}

The authors declare no conflicts of interest regarding the publication of this paper.

\section{References}

[1] Simmonds, I. and Rudeva, I. (2012) The Great Arctic Cyclone of August 2012. Geophysical Research Letters, 39, L23709. https://doi.org/10.1029/2012GL054259

[2] Parkinson, C.L. and Comiso, J.C. (2013) On the 2012 Record Low Sea Ice Cover: Combined Impact of Preconditioning and an August Storm. Geophysical Research Letters, 40, 1356-1361. https://doi.org/10.1002/grl.50349

[3] Melillo, J., Richmond T. and Yohe, G., Eds. (2014) USGCRP, 2014: Climate Change Impacts in the United States Tech. Rep. US Global Change Research Program, Washington DC.

[4] Knudsen, E.M. and Walsh, J.E. (2016) Evaluation of Northern Hemisphere Storminess in the Norwegian Earth System Model. Geoscientific Model Development, 9 , 2335-2555. https://doi.org/10.5194/gmd-9-2335-2016

[5] Collins, M., Knutti, R., Arblaster, A.M., Dufresne, J.L., Fichefet, T., Friedlingstein, P., Gao, X., Gutowski, W.J., Johns, T., Krinner, G., Shongwe, M., Tebaldi, C., Weaver, A.J. and Wehner, M. (2013) Long-Term Climate Change: Projections, Commitments and Irreversibility. Climate Change 2013: The Physical Science Basis. Contribution of Working Group I to the Fifth Assessment Report of the Intergovernmental Panel on Climate Change. Cambridge University Press, Cambridge.

[6] AMAP (2017) Snow, Water, Ice and Permafrost in the Arctic: 2017 Update. Arctic Monitoring and Assessment Programme, Oslo, xiv +269 p.

[7] Bekryaev, R., Polyakov, I. and Alexeev, V. (2010) Role of Polar Amplification in Long-Term Surface Air Temperature Variations and Modern Arctic Warming. Journal of Climate, 23, 3888-3906. https://doi.org/10.1175/2010JCLI3297.1

[8] AMAP (2011) Snow, Water, Ice and Permafrost in the Arctic. Arctic Monitoring and Assessment Programme, Oslo, Norway, xii +538 p.

[9] Stocker, B.D., Roth, R., Joos, F., Spahni, R., Steinacher, M., Zaehle, S., Bouwman, L., $\mathrm{Xu}, \mathrm{R}$. and Prentice, I.C. (2013) Multiple Greenhouse-Gas Feedbacks from the Land Biosphere under Future Climate Change Scenarios. Nature Climate Change, 3, 666-672. https://doi.org/10.1038/nclimate1864

[10] AMAP (2005) Arctic Climate Impact Assessment. Arctic Monitoring and Assessment Programme, Oslo, 1042 p.

[11] Harvey, B.J., Shaffrey, L.C. and Woolings, T.J. (2015) Equator-to-Pole Temperature Differences and the Extra-Tropical Storm Track Responses of the CMIP5 Climate Models. Climate Dynamics, 43, 1171-1182. https://doi.org/10.1007/s00382-013-1883-9

[12] Ulbrich, U., Leckebusch, G.C. and Pinto, J.G. (2009) Extra-Tropical Cyclones in the Present and Future Climate: A Review. Theoretical and Applied Climatology, 96, 117-131. https://doi.org/10.1007/s00704-008-0083-8

[13] Barnes, E.A. and Screen, J.A. (2015) The Impact of Arctic Warming on the Midlatitude Jet-Stream: Can It? Has It? Will It? WIREs Climate Change, 6, 277-286. https://doi.org/10.1002/wcc.337

[14] Basu, S., Zhang, X. and Wang, Z. (2018) Eurasian Winter Storm Activity at the End of the Century: A CMIP5 Multi-Model Ensemble Projection. Earth's Future, 6, 61-70. https://doi.org/10.1002/2017EF000670 
[15] Zhang, X., Walsh, J.E., Zhang, J., Bhatt, U.S. and Ikeda, M. (2004) Climatology and Interannual Variability of Arctic Cyclone Activity, 1948-2002. Journal of Climate, 17, 2300-2317.

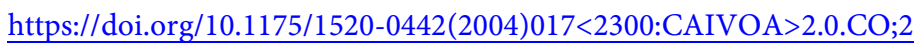

[16] McCabe, G., Clark, M. and Serreze, M. (2001) Trends in Northern Hemisphere Surface Cyclone Frequency and Intensity. Journal of Climate, 14, 2763-2768. https://doi.org/10.1175/1520-0442(2001)014<2763:TINHSC>2.0.CO;2

[17] Wang, X., Swail, V. and Zwiers, F. (2006) Climatology and Changes of Extratropical Cyclone Activity: Comparison of ERA-40 with NCEP-NCAR Reanalysis for 1958-2001. Journal of Climate, 19, 3145-3166. https://doi.org/10.1175/JCLI3781.1

[18] Wang, X., Feng, Y., Compo, G., Swail, V., Zwiers, F., Allen, R. and Sardeshmukh, P. (2013) Trends and Low Frequency Variability of Extra-Tropical Cyclone Activity in the Ensemble of Twentieth Century Reanalysis. Climate Dynamics, 40, 2775-2800. https://doi.org/10.1007/s00382-012-1450-9

[19] Mesquita, M., Atkinson, D. and Hodges, K. (2010) Trends in Northern Hemisphere Surface Cyclone Frequency and Intensity. Journal of Climate, 14, 2763-27678.

[20] Karl, T.R., Melillo, J.M. and Peterson, T.C. (2009) Global Climate Change Impacts in the United States. U.S. Global Change Research Program, Cambridge University Press, Cambridge.

[21] Moss, R.H., Edmonds, J.A., Hibbard, K.A., Manning, M.R., Rose, S.K., van Vuuren, D.P., Carter, T.R., Emori, S., Kainuma, M., Kram, T., Meehl, G.A., Mitchell, J.F., Nakicenovic, N., Riahi, K., Smith, S.J., Stouffer, R.J., Thomson, A.M., Weyant, J.P. and Wilbanks, T.J. (2010) The Next Generation of Scenarios for Climate Change Research and Assessment. Nature, 463, 747-756.

https://doi.org/10.1038/nature08823 http://www.nature.com/doifinder/10.1038/nature08823

[22] Walsh, J.E., Chapman, W.L., Romanovsky, V., Christensen, J.H. and Stendel, M. (2008) Global Climate Model Performance over Alaska and Greenland. Journal of Climate, 21, 6156-6174. https://doi.org/10.1175/2008JCLI2163.1

[23] Lader, R., Walsh, J.E., Bhatt, U.S. and Bieniek, P.A. (2017) Projections of Twenty-First-Century Climate Extremes for Alaska via Dynamical Downscaling and Quantile Mapping. Journal of Applied Meteorology and Climatology, 56, 2393-2409. https://doi.org/10.1175/JAMC-D-16-0415.1

[24] Hayhoe, K. (2010) A Standardized Framework for Evaluating the Skill of Regional Climate Downscaling Techniques. PhD Thesis, Dept. of Atmospheric Sciences, University of Illinois at Urbana, Champaign, $153 \mathrm{p}$.

[25] Bureau of Reclamation (2013) Downscaled CMIP3 and CMIP5 Climate Projections Release of Downscaled CMIP5 Climate Projections, Comparison with Preceding Information, and Summary of User Needs. U.S. Department of the Interior, Bureau of Reclamation, $104 \mathrm{p}$.

https://gdo-dcp.ucllnl.org/downscaled_cmip_projections/techmemo/BCSD5Hydrol ogyMemo.pdf

[26] Walsh, J.E., Bhatt, U.S., Littell, J.S., Leonawicz, M., Lindgren, M.A., Kurkowski, T.A., Bieniek, P., Thoman, R., Gray, S. and Rupp, T.S. (2018) Downscaling of Climate Model Output for Alaskan stakeholders. Environmental Modeling and Software. https://doi.org/10.1016/j.envsoft.2018.03.021

[27] Serreze, M.C. and Barrett, A.P. (2011) Characteristics of the Beaufort Sea High. Journal of Climate, 24, 159-182. https://doi.org/10.1175/2010JCLI3636.1

[28] Gleicher, K.J., Walsh, J.E. and Chapman, W.L. (2011) A Vorticity-Based Analysis of 
the Spatial and Temporal Characteristics of the Beaufort Anticyclone. Journal of Geophysical Research (Armospheres), 116, D18115.

[29] Day, J.J. and Hodges, K.I. (2018) Growing Land-Sea Temperature Contrast and Intensification or Arctic Cyclones. Geophysical Research Letters, 45, 3673-3681. 